\title{
PHENYLALANINE AMMONIA-LYASE ACTIVITY AND ANTHOCYANIN CONTENT IN DIFFERENT VARIETIES OF LETTUCE UNDER THE CADMIUM INFLUENCE
}

\author{
O. I. KOSYK, I. M. KHOMENKO, L. M. BATSMANOVA, N. YU. TARAN \\ Educational and Scientific Centre "Institute of Biology and Medicine", \\ Taras Shevchenko National University of Kyiv; \\ e-mail: i.m.homenko@gmail.com
}

Cadmium ions influence on the content of anthocyanins as non-plastid pigments and the activity of phenylalanine ammonia-lyase (EC 4.3.1.24) as primary enzyme of their biosynthesis in two lettuce varieties (Lactuca sativa L.) with different anthocyanin content was investigated. The increases in anthocyanin content and enzymatic activity of phenylalanine ammonia-lyase of both lettuce plant varieties during the 14-day exposure in solution of cadmium nitrate $(0.1 \mathrm{mmol})$ were established. The difference in levels of adaptive capacity in two lettuce varieties with different content of anthocyanins under the effect of cadmium ions was revealed. The indexes of tolerance have shown faster adaptive response and higher resistance in red variety plants, compared with plants of the green lettuce variety. These data are consistent with the corresponding changes in anthocyanins content and indicate their active participation in neutralizing the negative impact of cadmium stress.

Key words: cadmium ions, anthocyanins, phenylalanine ammonia-lyase, tolerance index, resistance, Lactuca sativa.

$\mathrm{T}$ he increasing of anthropo-technological load [1] is accompanied with environmental accumulation of cadmium compounds, one of the most common first class toxicity pollutants [2]. This statement necessitates the research of its toxic effect mechanisms on plant organisms and determination of the physiological and biochemical adaptive changes in plant cell metabolism [3, 4].

Plants resistance ability to the high environmental concentrations of cadmium depends on: plant genotype, stage of development and metal concentration, and it is achieved by activation of the induced resistance mechanisms [5]. The support of antioxidant status appropriate level and plant cell ability to the cadmium ions chelation are considered as one of the main intracellular mechanisms of plant resistance to toxic cadmium effect [6]. Such properties are inherent in endogenous low molecular weight phenolic metabolites - anthocyanins that play a significant role in the formation of plant adaptive mechanisms to adverse environmental conditions $[6,7]$. Anthocyanins are also important low molecular weight component of the plant antioxidant system. They show both direct and indirect antioxidant action associated with chelation of metal ions with variable valence [8]. Therefore, plant organism is characterized by the increase of phenylpropanoid biosynthesis intensity under the influence of stress factors, and their accumulation level serves as a nonspecific indicator of plant stability $[9,10]$. Phenylalanine ammonia-lyase (PAL, L-Phenylalanine Ammonia-Lyase EC 4.3.1.24) is a regulatory enzyme of the secondary metabolism compound biosynthesis that catalyzes the primary reaction of reverse deamination of L-phenylalanine amino acid to the trans-cinnamic acid [11, 12]. Therefore the PAL in the plant organism can play an extremely important role to run the resistance mechanisms against the toxic effects of stress factors, including cadmium [10, 13].

It is known that lettuce (Lactuca sativa L.) and other leafy vegetables being dietary multivitamin daily cultures of human nutrition [14] with a rapid biomass growth could be considered as potential heavy-metal accumulators $[15,16]$. Despite

(C) 2017 Kosyk O. I. This is an open-access article distributed under the terms of the Creative Commons Attribution License, which permits unrestricted use, distribution, and reproduction in any medium, provided the original author and source are credited. 
the known fact about genetic determination of plant ability to heavy metal accumulation at the family, genus and species level, the results of this fact confirmation at the variety level have appeared recently [1].

It was discovered $[12,17]$ responsible for the secondary phenolic metabolites synthesis R2R3Myb-domains and bHLH-transcription factors of plant genome that could act as driving factors for differently pigmented varieties selection. The largescale research of various EST-domains of lettuce (L. sativa) plant genome identified the gene expression increase of the enzymatic units in anthocyanin synthesis under stress conditions, in particular the genes responsible for encoding the PAL-biosynthesis $[17,18]$.

The aim of the study was to assess the impact of exogenous cadmium ions to anthocyanin content and PAL-activity to determine the varietal characteristics of different anthocyanin content varieties of lettuce resistance (L. sativa L. var. crispa).

\section{Materials and Methods}

Two varieties of lettuce plants (L. sativa L. var. crispa) significantly differing in anthocyanin content - green Lolo and red Lolo Ross were grown over the month by the water culture with half diluted Knop nutrient solution under $25^{\circ} \mathrm{C}$ and 16-hour photoperiod conditions. The $0.1 \mathrm{mmol}$ cadmium nitrate solution $\left(\mathrm{Cd}\left(\mathrm{NO}_{3}\right)_{2} \cdot 4 \mathrm{H}_{2} \mathrm{O}\right)$ was added in the nutritional environment of lettuce experimental variants. The coeval control and test plants were randomly selected for physiological and biochemical assays in the $1^{\text {st }}, 7^{\text {th }}$ and $14^{\text {th }}$ day of exposure.

Anthocyanin pigment content was estimated spectrophotometrically by the method of Beggs and Wellmann [19] with some minor modifications. The crushed leaves sample material $(0.5 \mathrm{~g})$ was extracted with $10 \mathrm{ml}$ of $\mathrm{HCl}$ :methanol solution (at a ratio of 1:100) during $24 \mathrm{~h}$ at $5{ }^{\circ} \mathrm{C}$ temperature of the environment. Absorbance was measured by a UV-1800 (Shimadzu, Japan) at $530 \mathrm{~nm}$ wavelength. Quantity of anthocyanin was calculated according to Giusti and Wrolstad methodology [20] using cyanidin3 -glucoside coefficients - the major anthocyanin in lettuce plants according to $\mathrm{Wu}$ and Prior [21] (molar extinction coefficient of $26900 \mathrm{l} \cdot \mathrm{cm}^{-1} \cdot \mathrm{mol}^{-1}$ and molecular weight of $449.2 \mathrm{~g} \cdot \mathrm{mol}^{-1}$ ).

PAL activity was determined according to Zucker methodology [22] with some modification $[11,13]$ and minor additions. The spectrophotomet- ric determination of PAL is based on changes of absorbance at $290 \mathrm{~nm}$ compared to the resulting mixture with stopped enzyme reaction at the beginning of heating as blank. For enzyme analysis $0.2 \mathrm{~g}$ of fresh leaves were homogenised in $3 \mathrm{ml}$ borate buffer (pH 8.8) containing $23 \mu \mathrm{l}$ of mercaptoethanol. Extraction was performed at $2{ }^{\circ} \mathrm{C}$. The homogenates were centrifuged for $20 \mathrm{~min}$ at $8000 \mathrm{~g}$ and the supernatant was used for enzymatic assay. The PAL assay system contained $1 \mathrm{ml}$ of the supernatant, $1 \mathrm{ml}$ of buffer, $1 \mathrm{ml}$ of $0.05 \mathrm{M} \mathrm{L}$-phenylalanine as a substrate was incubated at $37^{\circ} \mathrm{C}$ for $1 \mathrm{~h}$. The reaction was stopped with $30 \%$ trichloroacetic acid and absorbance of the formed trans-cinnamic acid was measured at $290 \mathrm{~nm}$ wavelength. The results of PAL activity were expressed as $\mu$ moles of trans-cinnamic acid per minute per milligram of protein ( $\mu$ moles trans-cinnamic acid $\mathrm{min}^{-1} \mathrm{mg}^{-1}$ ). Protein content was determined by the method of Bradford [23].

$\mathrm{Cd}$ tolerance index, as one of the main integral indicators of plant resistance [24, 25], was determined by the formula: $\mathrm{TI}=$ Dry weight $(+0.1 \mathrm{mmol}$ $\mathrm{Cd}^{2+}$ )/Dry weight (control) $\times 100 \%[26,27]$.

Statistical analysis of the results obtained was carried out with three biological and analytical replicates. The arithmetic mean value, standard deviation $(\mathrm{M} \pm \mathrm{SD})$ and correlative analysis with Pearson coefficients were performed using the standard program of "Microsoft Office" package - "Microsoft Office Excel". Differences were accepted as significant by the Student's criterion for $P \leq 0.05$.

\section{Results and Discussion}

Inhibition of plant growth is one of the first nonspecific reactions and early symptom of a visual display of heavy metal negative effects. Plant growth parameter is most sensitive to changes of nutritional medium composition and most clearly reveals the systemic response to high heavy metals content. Therefore, the stability of the plant growth parameters under the contaminated territories is one of the main integral indicators of tolerance to environment conditions [24].

Using the dry mass, as an integral indicator of the absolute growth, we investigated the tolerance indexes that was based on biomass growth and showed the differences in plant response during the exposure to the presence of $\mathrm{Cd}^{2+}$ ions [25]. The data obtained (Fig. 1.) indicate the difference in the levels of adaptive capacity of the various anthocyanin content lettuce varieties to the cadmium ions 


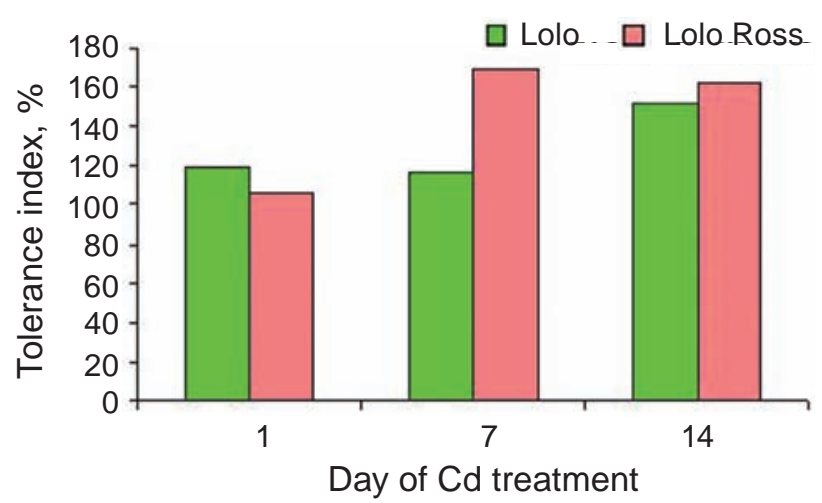

Fig. 1. Tolerance indexes of L. sativa green Lolo and red Lolo Ross varieties at the $0.1 \mathrm{mmol} \mathrm{Cd}^{2+}$ influence

influence. In particular, the test plants of red Lolo Ross variety showed faster and higher resistance occurred at the $7^{\text {th }}$ exposure day compared to experimental green Lolo variety plants, which has reached the relevant level only at the $14^{\text {th }}$ exposure day. It can be explained by the involvement of anthocyanins, low molecular weight endogenous antioxidants and chelators, in the plant adaptive response processes $[6,12]$. Because it is known that this group of phenolic compounds have the ability to form chelate complexes with heavy metals [4], transporting them into the vacuole for detoxification, and also affect the membrane fluidity, reducing the flow of hazardous ions into the cell $[9,28]$.

The results indicated a significant increase in the pool of anthocyanin pigments in the experimental plants of both varieties under the influence of cadmium ions (Fig. 2). However, we identified significantly higher anthocyanin levels in the experimental plant of red Lolo Ross lettuce variety, which grew throughout the exhibition, reaching maximum values on the $7^{\text {th }}$ day and surpassing control plants value by $80 \%$ (Fig. $2, B$ ).

A higher level of non-plastid pigment accumulation in red lettuce is a varietal characteristic. However, its significant increase throughout the experiment could obviously testify to developed chelator metabolism and non-plastid pigment active participation in the negative impact of this heavy metal neutralization. The consistently high anthocyanin content during prolonged stressor exposure may also indicate the activation of its synthesis at the time of the previous reserves depletion and is consistent with scientist assertions about the antioxidant role of phenolic compounds in oxidative stress combating $[3,9]$.

At the same time, the experimental plants of Lolo lettuce variety showed a significant increase in the anthocyanin content by $30 \%$ only on the first day of exposure with cadmium ions (Fig. 2, A). Further anthocyanin reduction in treated plants throughout the exposition can testify to their active opposition to the $\mathrm{Cd}^{2+}$ toxic effects by mass deposition of the formed metal complexes in vacuoles, which is one of the main manifestations of non-plastid pigment protective functions in the plant organism under the influence of stress factors [7].

Thus, our results confirm the important role of phenolic compounds (anthocyanins) as antioxidants and chelators in the formation of adaptive plant response to the adverse effects of heavy metal ions.

As PAL is a key enzyme in a pool of secondary fenolic metabolite biosynthesis [13], changes in its activity levels under $\mathrm{Cd}$ toxicity could be regarded as the non-specific indicator of plant adaptive capacity,
$\boldsymbol{A}$

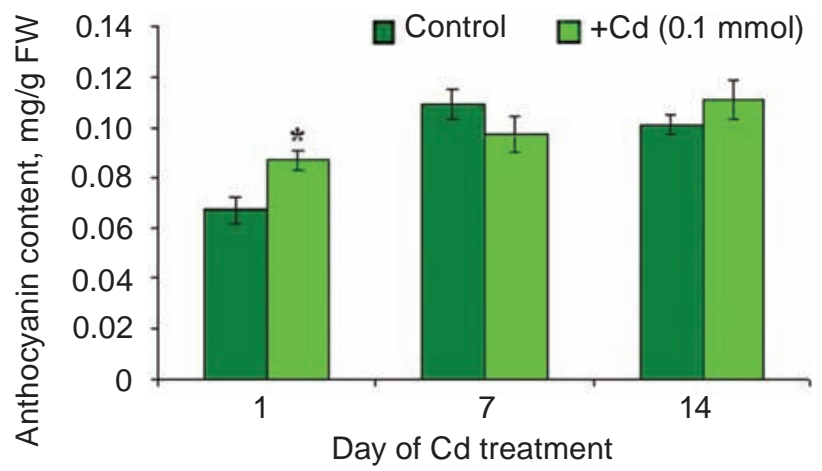

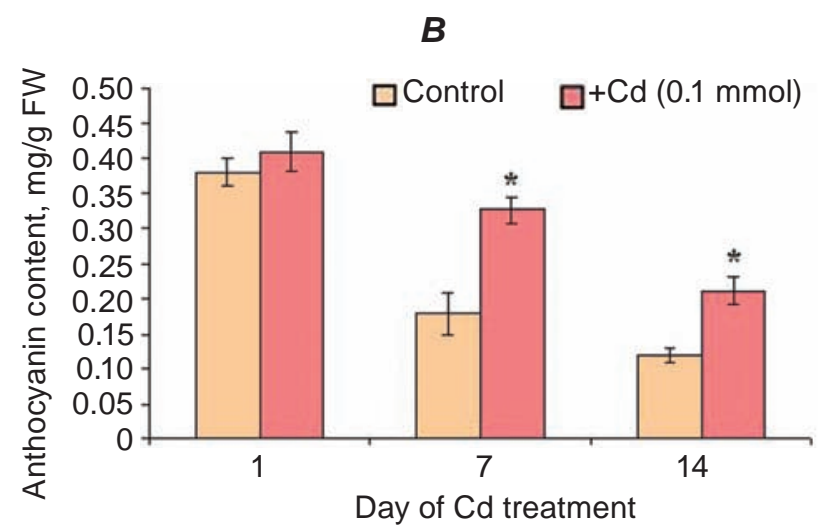

Fig.2. Anthocyanin content in leaves of Lolo (A) and Lolo Ross (B) varieties of L. sativa at the $0.1 \mathrm{mmol} \mathrm{Cd}^{2+}$ influence. *Difference compared with control statistically significant at $P<0.05, F W-$ fresh weight 
A

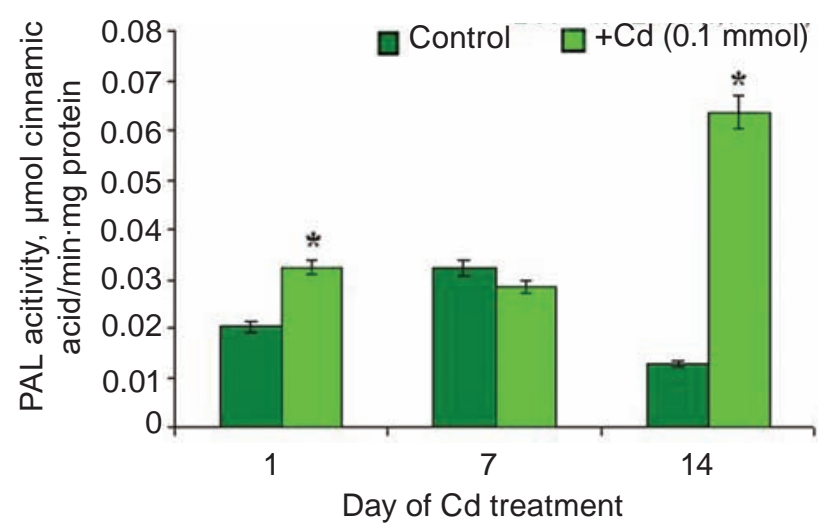

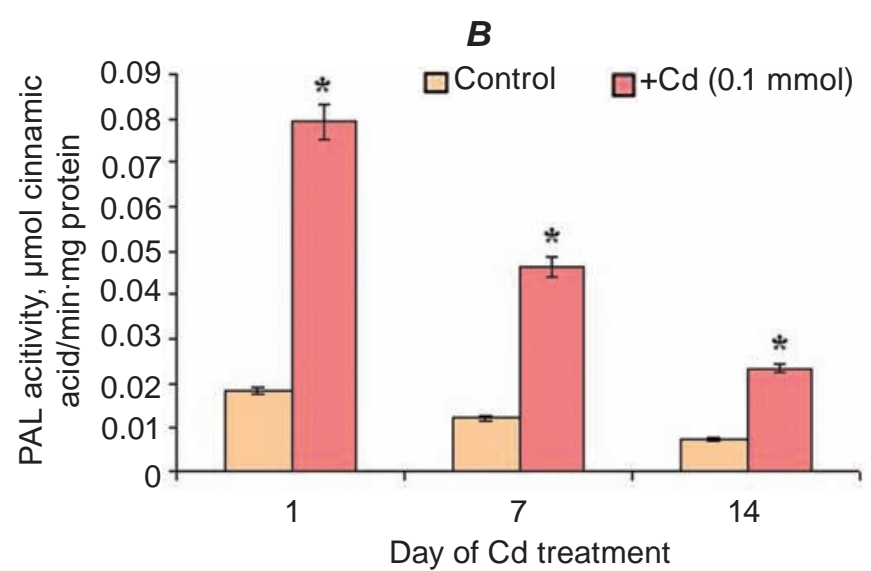

Fig. 3. PAL-activity in leaves of Lolo (A) and Lolo Ross (B) varieties of L. sativa at the 0.1 mmol $\mathrm{Cd}^{2+}$ influence. ${ }^{*}$ Difference compared with control statistically significant at $P<0.05$

which is manifested as increased synthesis of low molecular weight antioxidants and chelators [4].

According to our research, high anthocyanin accumulation levels in plants of both lettuce varieties under the cadmium influence during the experiment are consistent with a significant increase in the PAL activity. It was confirmed by the correlative analysis, according to which the high positive correlation with Pearson coefficients for green Lolo variety -0.851 and red Lolo Ross variety -0.987 was traced.

According to the data obtained a significant (60\%) increase of PAL activity above control was identified in the experimental green Lolo plants on the first day of cadmium exposure, which confirmed by the data presented in the literature $[11,12]$ about the fast enzyme response and was consistent with the increase of anthocyanin content in this variety plants at the first exposure day. The reducing of enzymatic activity in test samples by $12 \%$ below control was consistent with corresponding anthocyanin content decrease and could be explained by the inclusion of additional plant protection systems because of toxic effects of heavy metals. According to experimental data the maximum level of PAL activity for green Lolo variety was identified on the $14^{\text {th }}$ exposure day and reached up to six-time control values (Fig. 3, A).

In red Lolo Ross lettuce plants a gradual drop in PAL activity was observed during the $\mathrm{Cd}^{2+}$ treatment and consistent with an anthocyanin content decrease and could be explained by the secondary metabolite biosynthesis system sensitivity. The maximal level of red Lolo Ross PAL activity was identified on the first day of treatment and reached up to four-fold control values (Fig. 3, B). Further cadmium exposure showed the three-fold increasing of enzyme activity on the $14^{\text {th }}$ day.

Thus, according to the data obtained, we can say that the influence of cadmium ions activates this enzyme in red lettuce plants as evidenced by the significantly higher PAL activity level, which is stored within the experiment.

Thus, the different levels of phenylalanine ammonia-lyase activity in the plants of two lettuce varieties significantly differing in anthocyanin content during prolonged exposure with $0.1 \mathrm{mmol} \mathrm{Cd}^{2+}$ was noted. The high tolerance index of experimental red lettuce plants allows us to suggest a more intense involvement of their adaptation processes to detoxify cadmium ions compared to experimental plants of green variety. Therefore, it is assumed that due to the presence of significant anthocyanin amounts, which effectively neutralized the negative effects of this toxicant exposure, red Lolo Ross variety showed a higher level of system stability under the cadmium influence compared to experimental plants of green Lolo variety. At the same time, a significant increase of the level of anthocyanin content at the $\mathrm{Cd}^{2+}$ impact in the test samples of both lettuce varieties both is consistent with the high enzyme activity of phenylalanine ammonia-lyase - the key enzyme in a low molecular weight antioxidants and fenolic chelator biosynthesis and also could be regarded as the nonspecific indicator of plant adaptive capacity. 


\section{АКТИВНІСТЬ ФЕНІЛАЛАНІН \\ АМІАК-ЛІАЗИ ТА ВМІСТ \\ АНТОЦІАНІВ У САЛАТІ РІЗНИХ СОРТІВ ЗА ДІЇ ІОНІВ КАДМІЮ}

\section{О. І. Косик, І. М. Хоменко, Л. М. Бацманова, Н. Ю. Таран}

\author{
ННЦ «Інститут біології та медицини», \\ Київський національний університет \\ імені Тараса Шевченка, Україна; \\ e-mail: i.m.homenko@gmail.com
}

Досліджено вплив іонів кадмію на вміст непластидних пігментів - антоціанів та активність основного ензиму ї біосинтезу - фенілаланін аміак-ліази (4.3.1.24) в двох сортах салату посівного (Lactuca sativa L.), що містять різну кількість антоціанів. Встановлено підвищення вмісту антоціанів та зростання активності фенілаланін аміак-ліази впродовж 14-добової експозиції рослин салату обох сортів у розчині нітрату кадмію (0,1 ммоль). Виявлено різницю в рівнях адаптаційної спроможності салату різних сортів за вмістом антоціанів до дії іонів кадмію. За індексами толерантності відзначено швидшу адаптивну відповідь та вищу резистентність у рослин червоного сорту салату, що узгоджується із відповідними змінами вмісту антоціанів та свідчить про їх активну участь у зниженні негативного впливу кадмієвого стресу.

К л ю чо в і слов в: антоціани, фенілаланін аміак-ліаза, індекс толерантності, іони кадмію, стійкість, Lactuca sativa.

\section{АКТИВНОСТЬ ФЕНИЛАЛАНИН АММИАК-ЛИАЗЫ И СОДЕРЖАНИЕ АНТОЦИАНОВ В САЛАТЕ РАЗЛИЧНЫХ СОРТОВ ПОД ДЕЙСТВИЕМ ИОНОВ КАДМИЯ}

О. И. Косык, И. М. Хоменко, Л. М. Бацмманова, Н. Ю. Таран

\author{
УНЦ «Институт биологии и медицины», \\ Киевский национальный университет \\ имени Тараса Шевченко, Украина; \\ e-mail: i.m.homenko@gmail.com
}

Исследовано влияние ионов кадмия на содержание непластидних пигментов - антоцианов и активность основного энзима их биосинтеза - фенилаланин аммиак-лиазы (4.3.1.24) в двух сортах салата посевного (Lactuca sativa L.), с различным содержанием антоцианов. Установлено повышение антоцианов и активности фенилаланин аммиак-лиазы при 14-суточной экспозиции салата обоих сортов в растворе нитрата кадмия (0,1 ммоль). Показано, что уровни адаптационной способности к действию ионов кадмия у обоих сортов салата различны. Оценка индексов толерантности показала более быстрый адаптивный ответ и более высокий уровень резистентности у растений салата красного сорта, что согласуется с соответствующими изменениями содержания антоцианов и свидетельствует об их активном участии в снижении негативного влияния кадмиевого стресса.

К л ю че в ы е с л о в а: антоцианы, фенилаланин аммиак-лиаза, индекс толерантности, ионы кадмия, устойчивость, Lactuca sativa. 


\section{References}

1. Chen W, Li L, Chang AC, Wu L, Kwon S-I, Bottoms R. Cadmium uptake by lettuce in fields treated with cadmium-spiked phosphorus fertilizers. Commun Soil Sci Plant Anal. 2009; 40(7-8): 1124-1137.

2. Hasan SA, Fariduddin Q, Ali B, Hayat S, Ahmad A. Cadmium: toxicity and tolerance in plants. J Environ Biol. 2009; 30(2): 165-174.

3. Monteiro C, Santos C, Pinho S, Oliveira H, Pedrosa T, Dias MC. Cadmium-induced cytoand genotoxicity are organ-dependent in lettuce. Chem Res Toxicol. 2012; 25(7): 1423-1434.

4. Shahid M, Dumat C, Khalid S, Niazi NK, Antunes PM. Cadmium bioavailability, uptake, roxicity and detoxification in soil-plant system. Rev Environ Contam Toxicol. 2017; 241: 73-137.

5. Hall JL. Cellular mechanisms for heavy metal detoxification and tolerance. $J$ Exp Bot. 2002; 53(366): 1-11.

6. Fedenko VS. Cyanidin complexation with metal ions. Ukr Biokhim Zhurn. 2006; 78(2): 149-152. (In Ukrainian).

7. Sharma SS, Dietz KJ, Mimura T. Vacuolar compartmentalization as indispensable component of heavy metal detoxification in plants. Plant Cell Environ. 2016; 39(5): 1112-1126.

8. Es-Safi NE, Ghidouche S, Ducrot PH. Flavonoids: hemisynthesis, reactivity, characterization and free radical scavenging activity. Molecules. 2007; 12(9): 2228-2258.

9. Chechui HF. The phenolic compounds content in germinating soybean seeds under oxidative stress caused by cobalt and cadmium ions. Physiology Biochem Cultiv Plants. (Fiziol Biohim Kult Rasten). 2011; 43(4): 362-366. (In Ukrainian).

10. Pawlak-Sprada S, Arasimowicz-Jelonek M, Podgórska M, Deckert J. Activation of phenylpropanoid pathway in legume plants exposed to heavy metals. Part I. Effects of cadmium and lead on phenylalanine ammonialyase gene expression, enzyme activity and lignin content. Acta Biochim Pol. 2011; 58(2): 211-216.

11. Smirnov O, Kosyan A, Kosyk O. The cycocel effect on flavonoids content and phenylalanine ammonia-lyase (PAL) activity in buckwheat (Fagopyrum esculentum Moench.) plant. Studia Biologica. 2012; 6(3): 247-252.
12. Vogt T. Phenylpropanoid biosynthesis. Mol Plant. 2010; 3(1): 2-20.

13. Smirnov OE, Kosyan AM, Kosyk OI, Taran NY. Response of phenolic metabolism induced by aluminium toxicity in Fagopyrum esculentum Moench. plants. Ukr Biochem J. 2015; 87(6): 129-135.

14. Yang D, Guo Z, Green ID, Xie D. Effect of cadmium accumulation on mineral nutrient levels in vegetable crops: potential implications for human health. Environ Sci Pollut Res Int. 2016; 23(19): 19744-19753.

15. Rafiq MT, Aziz R, Yang X, Xiao W, Stoffella PJ, Saghir A, Azam M, Li T. Phytoavailability of cadmium (Cd) to Pak choi (Brassica chinensis L.) grown in Chinese soils: a model to evaluate the impact of soil Cd pollution on potential dietary toxicity. PLoS One. 2014; 9(11): el11461.

16. Mulabagal V, Ngouajio M, Nair A, Zhang Y, Gottumukkala AL, Nair MG. In vitro evaluation of red and green lettuce (Lactuca sativa) for functional food properties. Food Chem. 2010; 118(2): 300-306.

17. Park JS, Kim JB, Cho KJ, Cheon CI, Sung MK, Choung MG, Roh KH. Arabidopsis R2R3MYB transcription factor AtMYB60 functions as a transcriptional repressor of anthocyanin biosynthesis in lettuce (Lactuca sativa). Plant Cell Rep. 2008; 27(6): 985-994.

18. Park JS, Choung MG, Kim JB, Hahn BS, Kim JB, Bae SC, Roh KH, Kim YH, Cheon CI, Sung MK, Cho KJ. Genes up-regulated during red coloration in UV-B irradiated lettuce leaves. Plant Cell Rep. 2007; 26(4): 507-516.

19. Jaleel CA, Wang G, Ahmad P, Ikram-ul-Haq. Changes in the photosynthetic characteristics of Catharanthus roseus L. as a result of exogenous growth regulators. Plant Omics J. 2009; 2(4): 169-174.

20. Giusti MM, Wrolstad RE. Characterization and Measurement of Anthocyanins by UV-Visible Spectroscopy. In: Wrolstad RE, Acree TE, Decker EA, Penner MH, Reid DS, Schwartz et al., editors. Handbook of food analytical chemistry. Hoboken: Wiley-Interscience; 2001. P. F1.2.1-F1.2.13.

21. $\mathrm{Wu} \mathrm{X}$, Prior RL. Identification and characterization of anthocyanins by high-performance liquid chromatography-electrospray ionizationtandem mass spectrometry in common foods in 
the United States: vegetables, nuts, and grains. J Agric Food Chem. 2005; 53(8): 3101-3113.

22. Zucker M. Induction of phenylalanine ammonialyase in Xanthium leaf disks. Photosynthetic requirement and effect of daylength. Plant Physiol. 1969; 44(6): 912-922.

23. Bradford MM. A rapid and sensitive method for the quantitation of microgram quantities of protein utilizing the principle of protein-dye binding. Anal Biochem. 1976; 72(1-2): 248-254.

24. Marchiol L, Assolari S, Sacco P, Zerbi G. Phytoextraction of heavy metals by canola (Brassica napus) and radish (Raphanus sativus) grown on multicontaminated soil. Environ Pollut. 2004; 132(1): 21-27.

25. Yang W, Ding Z, Zhao F, Wang Y, Zhang X, Zhu Z, Yang $X$. Comparison of manganese tolerance and accumulation among 24 Salix clones in a hydroponic experiment: Application for phytoremediation. J Geochem Explor. 2015; 149: 1-7.

26. Saleh M, Saleh Al-Garni. Increased heavy metal tolerance of cowpea plants by dual inoculation of an arbuscular mycorrhizal fungi and nitrogenfixer Rhizobium bacterium. Afr J Biotechnol. 2006; 5(2): 133-142.

27. Sai Kachout S, Ben Mansoura A, Ennajah A, Leclerc JC, Ouerghi Z and Karray Bouraoui N. Effects of metal toxicity on growth and pigment contents of annual halophyte (A. hortensis and A. rosea). Int J Environ Res. 2015; 9(2): 613-620.

28. Boiko I, Kobyletska M, Terek O. Salicylic acid as growth regulator for cadmium-stressed plants. Visnyk Lviv Univ. Series Biology. 2012; 58: 271279.

Received 27.12.2016 